\title{
SPECIFICS AND FEATURES OF OUTSOURCING MARKETING COMMUNICATIONS ACTIVITY
}

\section{Hajduk, G.}

The aim of this paper is to describe the outsourcing of marketing communications as a business trend. The author discusses possible scopes of external entities' involvement and presents positive and negative aspects of marketing communications outsourcing. Efficient use of modern forms of marketing communication is the domain of a highly specialized group of agencies and other providers of marketing services. The use of their creativity, competence and skills in the field of communication has a significant impact on its effectiveness. For many companies, it is currently more profitable to benefit from external specialists instead of hiring them and improving their competence within the organization. This solution also seems more beneficial with respect to the effectiveness of management and optimization of resources. However, given the importance of the brand as a company's most crucial intangible asset of strategic importance, delegating all decision-making power associated with it beyond the company is irrational. The choice of strategies and determination of key assumptions relating to integrated marketing communication should remain the responsibility of the parent company.

Keywords: Marketing communications; outsourcing; brand; marketing; strategy JEL Classification: M31, L86, L82, D83

\section{Introduction}

The scope of communication that takes place between companies and their clients and other target groups is expanding and evolving. The use of modern communication channels and tools requires increasingly specialized knowledge and skills. Information technologies are developing at a rapid pace and consumers benefit from their potential through modern devices and applications. The continuous development of the competencies of internal marketing personnel is difficult and expensive for businesses, which is one of the reasons they require the support of external specialists. As a result, certain marketing activities, which were carried out internally, are transferred outside of a company's organizational structure.

The phenomenon of employing agencies and other external marketing specialists is a well-established practice in business. Recent years show a significant increase in the scope of competencies and decision-making powers pertaining to marketing activities. It is known as marketing outsourcing. The trend started with outsourcing only a part of the marketing function: namely, advertising. Now, companies are outsourcing many marketing tasks. What used to be simple marketing tasks are now understood to be highly significant factors that can greatly help boost marketing success (Asefeso, 2011, p. 16). As the authors of "The Black Book of Outsourcing" point out - marketing is one of the really hot job categories in outsourcing today. Outsourcing marketing firms are beginning to make their move for market share (Brown, 2012, pp. 263, 265). 
Currently, the marketing activity of modern companies largely comes down to the exchange of information with the market environment. The aim of this paper is to describe marketing communications outsourcing as a trend and present the positive and negative aspects of it. The presented conclusions are based on the result of the author's own study and his professional experience in positions as a marketing communications consultant, communication manager and as a creative director at a marketing communication agency.

\section{Essence and Motives of Marketing Communication Outsourcing}

The need to use more and more advanced knowledge in business results in increasingly higher specialization of labor, favoring the spread of outsourcing. It has become a megatrend in business. The perception of outsourcing has evolved over the years. It has moved from initiatives that were financially motivated to the current stage of being strategically motivated. Strategically driven outsourcing efforts are capability - and competency-intensive. The focus here is to tap into specialized expertise, knowledge, processes and capabilities found outside the organization, and to use these as inputs to help improve the effectiveness and efficiency of operations (Power, 2006, pp. 5-6). Organizations are beginning to recognize the benefits of adopting approaches for managing across and beyond the boundaries of the organization (McIvor, 2005, p. 213). Outsourcing can now cover many business processes and decide about the companies' strategic market advantage.

In the literature we presented, there are many different definitions of outsourcing. Most often, it presents itself as the practice of hiring experts to handle functional business units, which are outside of your company's core business. It is also a method of staff augmentation without adding to head count (Dominguez, 2005, p. 5). Not all authors, however, believe that outsourcing is relevant only to auxiliary functions, i.e. those that are not related to the main area of accountability. According to M. Trocki, it involves separating certain functions of one company and transferring them to another (Trocki, 2001, p. 13). In its simplest form, specific, individual actions are subject to such a separation outside the company, while the most advanced transfers whole processes. Outsourcing is treated now increasingly as an umbrella term that includes a range of sourcing options that are external to the firm (Sanders, 2007, p. 3). As a result of globalization, many companies are opting for the separation of key processes beyond the country's borders. This is called offshoring. In general, the difference between outsourcing and offshoring comes down to the location of the service provider. Outsourcing refers to having work for a company done by another organization within the sovereign territory. Offshoring refers to having this work done in another country, whether or not it is done by part of the same company (Gupta, 2008, p. 322). With these kinds of strategic choices, companies gain economic benefits and increase the scale of operations.

According to the typology of outsourcing proposed by S. Cyfert and K. Krzakiewicz, outsourcing marketing can be distinguished using functional criterion. It can be an excluded from the company's structure as well as HR, IT, accounting, finance, retail, manufacturing and logistics. This exclusion makes sense if there are conditions for effective and efficient execution of these functions outside the company (Cyfert, 2009, p. 167), such as if the service provider is not only responsible for the acquired function or process, but also designs them in such a way as to make better use of existing resources of the client and the contractor. This concept is called Business Process Outsourcing (BPO). By streamlining the process, additional value for the company is being created (Foltys, 
2012, p. 57). BPO offers an opportunity in one fell swoop to encompass the back office in the change program - including the deployment of technology that, if implemented correctly, will improve effectiveness and efficiency by a factor of many hundreds of per cent (Bravard, 2006, p. 25). In the case of marketing communication, planning and implementation on behalf of the client can be entrusted to a full service agency. In this case, the company may opt out of maintaining their own department or the unit responsible for communication with the market focusing on other key business functions and processes.

Outsourcing of an important area of activity should be determined in the contract between the company and the ordering recipient. Contractual outsourcing as opposed to the capital, is realized by an entity not affiliated with their parent company capital (Radło, 2013 ,p. 35). The implementation of marketing communications should be integrated with and subordinated to the strategic assumptions, and contained in such documents as marketing strategy and brand strategy. The client implements, or proposes, or just realizes jointly agreed assumptions, among which are: the big idea, key messages, etc. The contract provides for the implementation of the premises, determines the responsibility and risk sharing between partners. It is worth noting that in this kind of contract there is usually asymmetry of information. The seller (bidder) has better information on available products and services than the purchaser does. Here, it may come to abuse by service providers - a moral hazard. Choosing a contractor, you also need to consider the criteria that cannot be defined. The mutual trust of participants is an important prerequisite for success in this case (Ciesielska, 2014, p. 85).

The influence of marketing outsourcing should be a key factor for consideration in planned outsourcing and learning research. Recently, many firms have outsourced their customer relationship management tools or systems (e.g. CRM programs, loyalty programs, and sales management) to consulting firms and other system developers. While CRM outsourcing may seem attractive at the management level considering investment cost and expertise, serious hazards are often encountered when they face serious losses in organizational learning for their markets and customers (Park, 2012, p. 471). The same thing happens with the wider area of marketing communications. Resignation from direct involvement in the decision-making process carries with it certain risks and may interfere with the realization of strategic objectives.

Outsourcing projects can be segmented by location, by their depth level and by examining the nature of work (Power, 2006, pp. 11-14):

1. Outsourcing efforts segmented by location, i.e. where the work is done:

- on-site - involves having members of the vendor's team conduct work within the premises of the client organization,

- $\quad$ off-site - the vendor conducts work at its location. Off-site work arrangements work can be onshore, near-shore and offshore.

2. Outsourcing projects segmented by their depth level:

- $\quad$ individual - outsourcing specific positions out of the organization (for example PR personnel),

- functional - outsourcing of an individual functional area, also known as a cost center (e.g. accounts payable),

- competency - outsourcing of activities that control how products or services flow through the organization (e.g. human resource management). 
3. Outsourcing efforts classified by examining the nature of work:

- $\quad$ process-oriented work - usually involves the outsourcing of a well-structured, standardized and documented process (for example, outsourcing of a payroll function),

- $\quad$ project-oriented work - involves the outsourcing of unique and non-routine, unstructured and non-standardized work, (for example software development).

Marketing communication outsourcing can be implemented at different depth levels; it may be process or project-oriented. Individual tasks, due to their specificity, are usually performed at the contractor's office. Their implementation is previously consulted with the client. The achieved results should be presented in the form of reports. An important idea stemming from the essence of outsourcing is the motivation to carry it out. The list of themes is very long, and can be divided into 3 main groups:

1. Economical - cost savings, changing the cost structure, increasing the efficiency of resource use, etc.

2. Related to the improvement of management - to focus on core business, increasing strategic freedom of action, simplification and reorganization of business processes, etc.

3. Regarding improvement of the efficiency on the market - improving customer service, increasing sales, increasing marketing effectiveness, etc.

In practice, the decision for outsourcing is usually based on a combination of different motives. Economical factors are an underlying reason for delegating non-core functions and tasks to external units. More efficient management of fewer employees can enable the better use of resources. In the case of marketing activity, the situation is somewhat different. It is associated with responding to customer needs and building relationships with them. Improper actions in this respect, or lack thereof, may squander sales opportunities of even very good, cheap products produced in an efficiently managed enterprise. The lack of skillful introduction to the market and the presentation to customers limits sales opportunities. It should be emphasized that the effectiveness of marketing communications depends not so much on the sum of expenditure but the relevance of the decisions on the content, forms and channels of communication. Efficient use of modern forms of marketing communication is the domain of highly specialized individuals. Taking advantage of their creativity, competence and skills in the field of communication has a significant impact on the scale of interest in the brand.

The transfer of the various functions outside the parent company should have the effect of reducing the cost of realization of objectives and goals, improve quality, reduce the level of employment, and increase adaptability to the changing environment. Not every situation regarding cooperation with external contractors of projects in the field of marketing communication can therefore be considered as outsourcing. The expected result should be an increase in efficiency as compared to a situation where this function is performed only with the involvement of the company's own resources. The separation of these areas of activity in the field of communication with the external environment can be called outsourcing of marketing communications which, when entrusted to external companies, will be conducted more effectively.

One of the challenges facing companies today is communication via social media. As the popularity of social networking sites such as Twitter, Facebook or YouTube is 
rising, companies need new business models and tools that include social functions. It is necessary to conduct marketing campaigns on popular social media platforms. Customers now expect or require urgent customer service out of office hours, so more brands are responding to queries via Twitter. Published in November 2015, the 2015 U.S. Retail Multichannel Customer Experience Study - surveying 500 US companies and 1,000 customers - found that $85 \%$ of customers expected a tweeted response within an hour, when it actually takes retailers an average of 31 hours to respond (Kasriel-Alexander, 2016, p. 8).

In order for the activities of companies and brands to bring a satisfactory effect, they need a fast and flexible reaction to the activity of the users. Interactivity of our communication is of key importance here. As social media monitoring companies report, the most effective social media profile authors are able to react to $100 \%$ of users' posts. ${ }^{1}$ The fastest reacting brands achieve an average reaction to users' post time in as short as 3 minutes. Such a level and scope of engagement requires $24 \mathrm{~h}$ our activity. Employing internal specialists responsible for this area of marketing activity could be ineffective. Firstly, we need highly specialized staff, able to process multiple channels of communication and functions and tools available. Secondly, it is a 24/7 occupation work, because social media life never stops. The company, whose marketing department or public relations work several hours a day has greatly reduced the possibility of using interactive communication with customers.

\section{The Scope and Forms of Marketing Communications Outsourcing}

The scope of outsourcing can vary in relation to exclusive decision-making powers left to the parent company. At least three general situations concerning the possible involvement of the ratio between internal and external resources in pursuit of marketing communications require consideration (Hajduk, 2013, pp. 129-130). It is best to determine their division with reference to levels of planning and the hierarchy of objectives in the company (Figure 1).

\section{Figure 1 | Possible proportions of the internal and external decisions and activities in the field of marketing communications}

Case 1.

without delegation

of decision-making power
Case 2.

delegation of all decision-making power
Case 3.

partial delegation of decision-making power

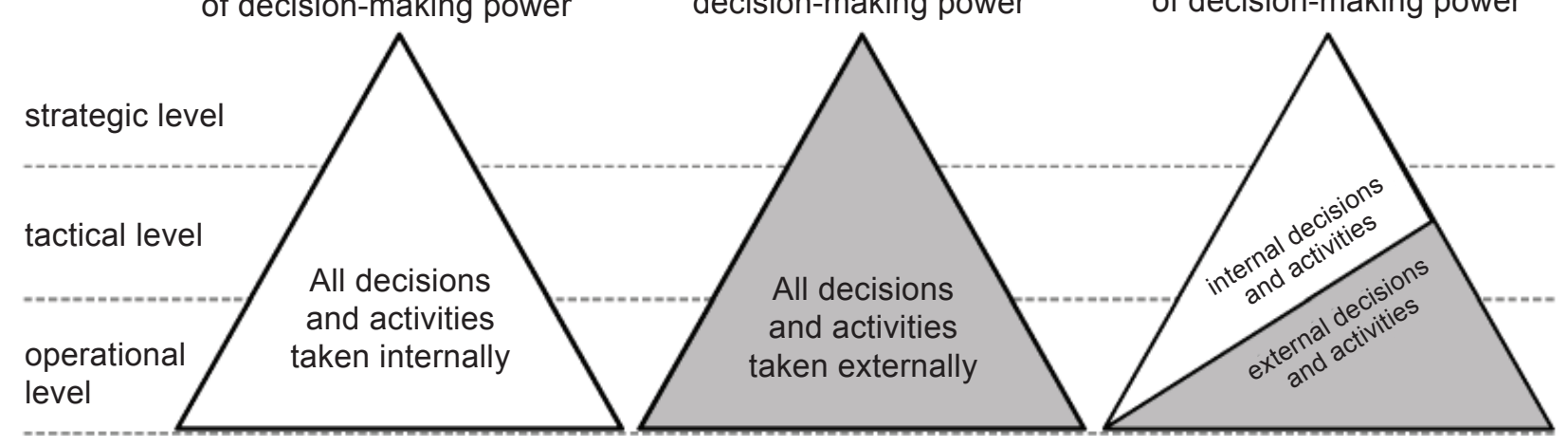

Source: author's own work.

1 In November of 2015, TVN Turbo and TUI Facebook profiles achieved 100\% of posts with users' responses. The lowest average response time was achieved by the T-mobile PL profile - 2 min 57 sec. Source Źródło: http://www.sotrender.pl/trends/facebook 
The first is an extreme case, which could be conceived of as the situation where all the decisions and the planning and implementation of activities in the field of marketing communications take place with the involvement of only the company's own resources. The company retains full control over decisions about building brand value, but it also limits their opportunities and possible increases in the effectiveness of interventions.

\section{Table 1 | Possible options of involvement of external contractors in the field of marketing communications at different levels of planning and a hierarchy of objectives of the company}

\begin{tabular}{|c|c|}
\hline 3.1 & $\begin{array}{l}\text { Delegation of powers only at the strategic level. In this rare case, the external } \\
\text { manager takes over management of marketing communications. Such a function } \\
\text { can be performed by a temporarily hired external Communication Manager. The } \\
\text { specificity of his work is close to the concept of Interim Management. According to } \\
\text { the definition proposed by the Interim Management Association, interim managers } \\
\text { are experienced executives with specialist skills and a proven track record of } \\
\text { success. They are hired by businesses on a project basis to solve problems. }{ }^{1}\end{array}$ \\
\hline 3.2 & $\begin{array}{l}\text { The delegation of power at the tactical level, while leaving the whole range of } \\
\text { strategic decisions in the field of marketing communication and the entire range } \\
\text { of tasks in the company. In this case, the company may benefit from a specialized } \\
\text { consultant or the support of a creative agency, whose effect is to obtain tactical } \\
\text { guidelines, which can later be independently implemented. }\end{array}$ \\
\hline 3. & $\begin{array}{l}\text { Outsourcing the implementation of the internally planned specific tasks to } \\
\text { a contractor, such as: marketing agencies, advertising and PR agencies, publishing } \\
\text { houses, freelancers, etc. }\end{array}$ \\
\hline 3 & $\begin{array}{l}\text { Such cooperation is usually with one full-service agency, which for the duration of } \\
\text { the contract assumes responsibility for both the planning and selection of forms } \\
\text { of media content and implementing various activities in the field of marketing } \\
\text { communications. Such plans are subordinated at the tactical level but strategic } \\
\text { supervision is maintained by the contractor who takes care of the implementation } \\
\text { of a long-term process of building brand equity. }\end{array}$ \\
\hline 3. & $\begin{array}{l}\text { A whole range of strategic decisions, such as choosing a brand positioning strategy } \\
\text { and defining key messages accompanying the brand is at the discretion of the client. } \\
\text { Some companies also retain the exclusivity of decisions on defining the tactics of } \\
\text { actions, and therefore the shape and scope of ongoing campaigns, media content or } \\
\text { the selection of channels. The external contractors are only entrusted with a greater } \\
\text { or lesser range of activities to achieve the internally formulated strategy. These are } \\
\text { services related to the implementation of promotional campaigns, telemarketing, } \\
\text { print, photography, graphic design, copywriting, creating and maintaining websites } \\
\text { and others. }\end{array}$ \\
\hline
\end{tabular}

Source: author's own work.

2 Definition of an interim manager taken from Interim Management Association, http://www. interimmanagement.uk.com/interim-managers/definition-of-an-interim-manager/. 
The opposite of this situation is complete outsourcing. It relies on entrusting the entire field of strategic decisions, tactical and operational information concerning communicating with the market to outside contractors. The main side effect of this approach, however, is loss of control over the brand. In the real life activities of companies directing their offer to mass audiences, both of these solutions are very rare.

The third possible orientation is to find a compromise between the scope of the decisions and actions taken internally and with the involvement of third parties.

The partial scope of authority assigned to an external contractor should be fixed very precisely in order to avoid later problems with the pursuit of goals and enforcement of responsibilities. With reference to the above case 3 , when the contractor is given partial authority, which might involve different levels of planning and a hierarchy of objectives in the company, we have a number of options (Table 1). The above division is related to the issue of cooperation with different numbers of external entities - from one to tens. Cooperation with one full-service agency allows us to simplify the management and control of your communication and to minimize the risk of leakage of sensitive information. The agency's offer is comprehensive and it is possible to achieve a high degree of integration of activities. The negative sides of such cooperation include high overheads and the possibility of too low a level of specialization in individual actions.

An alternative solution is simultaneous collaboration between several specialized bodies. The overall costs may be lower in this case, while maintaining the freshness of ideas and a high degree of professionalism of individual contractors. The negative features of this solution are the dispersion of contractors and the associated need to coordinate multiple projects simultaneously. There are also risks associated with sharing sensitive information among many entities.

When working with several entities, both time and effort can be reduced if the cooperation is between contractors. Common briefings, creative sessions, creating and approving strategic and tactical plans also reduces the risk of errors due to the participation of a wider group of experts representing different companies. Note, however, that usually these are entities competing with each other and so the desire to cooperate here is not obvious.

\section{Advantages and Disadvantages of Outsourcing Marketing Communications}

Outsourcing the marketing function to a marketing agency has distinct benefits including: the fact that the focus is on the customer; it is immersed in your whole business; it allows the maintenance of the right focus; it enhances speed and efficiency; it allows for integrated disciplines; and it ensures getting the job done right (Graham, 2007, pp. 16-17). To make an objective assessment of such activities we should juxtapose the positives and negatives of outsourcing marketing communications. The formulation of a general list of advantages and disadvantages is not easy due to the complexity of the previously described phenomenon. By creating it, the assumption was made that marketing outsourcing concerns passing on medium to long-term cooperation with external contractors who take over responsibility for the implementation of marketing communication within the environment. 


\section{Advantages:}

1. The ability to focus on core business.

2. Access to the knowledge and skills of specialists in narrow fields within marketing communications (e.g. CRM, social media marketing, media relations, content marketing, etc.).

3. The possibility of their own employees acquiring new knowledge and skills.

4. The ability to use many specialists simultaneously, without the need for full employment.

5. The ability to use the latest technology without incurring expenses associated with their purchase.

6. An increase in coverage thanks to the potential of partners (agencies, media companies, consulting companies, etc.).

7. An increase in the efficiency and speed of communication.

8. Greater flexibility and interactivity of communication

9. Better adaptation of the form and content of communication to customers' preferences.

10. The division of responsibilities and risks in the event of suitably constructed contracts.

\section{Disadvantages:}

1. A lack of full control over the activities undertaken on behalf of a company.

2. The possibility of losing control over a separate function.

3. The risk of departure from the strategic objectives relating to building brand equity.

4. The risk of disclosure of trade and market secrets.

5. Smaller commitment of their managers.

6. Possible higher expenses related to the presence of intermediaries and the use of their commission.

7. A lack of certainty that the proposed solutions are effective and not just profitable for agencies.

8. The limited ability to change communication strategies specified in the contract.

9. The difficulties and costs associated with the selection of the right company.

10. The possible loss of intuition and client insight.

Marketing communication carried out with the cooperation of and through a third party brings a lot of positives. In conditions of fierce competition and high intensity of company marketing activities, the support of professionals can significantly increase the effectiveness in communication with the market. They are able to achieve the objectives of the communication faster, more efficiently and more broadly. Reliance on their potential and competencies frees the company from a number of decision-making and organizational problems. This allows us to focus on the basic activity.

From representatives of senior marketing executives as well as the world of science, however, there are warnings about entrusting extremely important powers to entities that are focused on achieving their own profit. Attention is drawn to the increasing pressure 
on budgets correlated with the amount of commissions, media literacy, whose hiring would most benefit agencies, reaching for easy implementation of the action etc., but the most serious problem concerns the possibility of the parent company losing control over the brand. The functioning of the agencies does not meet the requirements of a rational, long-term policy of the brand. Even if the agency has its own network of partner companies, performs a wide range of services, and presents itself as a comprehensive integrated marketing communications producer, it does not eliminate all the problems. In addition, the agencies usually think in terms of campaign activity in the short-term (e.g. annual basis). Brand policy requires something else - the full integration of communication in the long-term.

\section{Conclusion}

The outsourcing of marketing communication is primarily concerned with greater opportunities and higher powers. Through the use of specialized knowledge, skills, ingenuity of external experts, it is possible to improve the effectiveness of marketing activities. The effectiveness of particular activities, however, does not guarantee the achievement of the effects of integrated marketing communications. To achieve a sustainable competitive advantage we need to take care of the strategic dimension of brand building process. The implementation of integrated marketing communication should involve both the performer and the businesses they support. This solution achieves the best result of actions taken and reduces the risk of errors.

\section{References}

Asefeso, A. (2011). Business Process Outsourcing Unleashed. Swindon: AA Global Sourcing Ltd.

Bravard, J. L., \& Morgan, R. (2006). Smarter Outsourcing: An Executive Guide to Understanding, Planning and Exploiting Successful Outsourcing Relationships. Pearson Education.

Brown, D., \& Wilson, S. (2012). The Black Book of Outsourcing: How to Manage the Changes, Challenges, and Opportunities. New York: John Wiley \& Sons.

Ciesielska, D., \& Radło, M. J. (2014). Outsourcing w praktyce. Warszawa: Poltext.

Cyfert, S., \& Krzakiewicz, K. (2009). Nauka o organizacji. Poznań: Towarzystwo Naukowe Organizacji i kierownictwa.

Dominguez, L. (2005). The Manager's Step-by-Step Guide to Outsourcing. New York: McGraw Hill Professional.

Foltys, J. (2012). Outsourcing w przedsiębiorstwach sektora mśp. Scenariusz aplikacyjny. Katowice: Wydawnictwo Uniwersytetu Śląskiego.

Graham, J. (2007). Outsourcing a company's marketing: a better way to meet competitive challenges. Supervision, 68(5), 15.

Gupta, A. (2008). Outsourcing and Offshoring of Professional Services: Business Optimization in a Global Economy. Hershey: IGI Global.

Hajduk, G. (2013). Outsourcing komunikacji marketingowej. Handel Wewnętrzny, 3(1), 127-134.

Kasriel-Alexander, D. (2016). Top 10 Global Consumer Trends for 2016. Euromonitor International. 
Mclvor, R. (2005). The Outsourcing Process: Strategies for Evaluation and Management. Cambridge: Cambridge University Press.

Park, J. E., Lee, S., \& Morgan, R. M. (2011). A negative side of outsourcing marketing functions and market-based learning process. Journal of Strategic Marketing, 19(5), 471-486.

Power, M. J., Desouza, K. C., \& Bonifazi, C. (2006). The Outsourcing Handbook: How to Implement a Successful Outsourcing Process. London: Kogan Page.

Radło, M. J. (2013). Offshoring i outsourcing. Implikacje dla gospodarki i przedsiębiorstw. Warszawa: Oficyna Wydawnicza SGH w Warszawie.

Sanders, N. R., Locke, A., Moore, C. B., \& Autry, C.W. (2007). A multidimensional framework for understanding outsourcing arrangements. Journal of Supply Chain Management, 43(4), 3-15.

Trocki, M. (2001). Outsourcing: metoda restrukturyzacji działalności gospodarczej. Warszawa: Polskie Wydawnictwo Ekonomiczne.

\section{Author}

\section{Grzegorz Hajduk PhD}

University of Rzeszów

Faculty of Economics

Department of Marketing and Entrepreneurship

ul. M. Ćwiklińskiej 2

35-601 Rzeszów, Poland

grzehaj@ur.edu.pl 